\title{
The Impact of Different Protein Content of Pollen on Honey Bee (Apis mellifera L.) Development
}

\author{
Zheko Radev \\ Faculty of Agriculture, Forestry and Natural Environment, Aristotle University, Thessaloniki, Greece \\ Email address: \\ duhovenmir@abv.bg

\section{To cite this article:} \\ Zheko Radev. The Impact of Different Protein Content of Pollen on Honey Bee (Apis mellifera L.) Development. American Journal of \\ Entomology. Vol. 2, No. 3, 2018, pp. 23-27. doi: 10.11648/j.aje.20180203.11
}

Received: September 20, 2018; Accepted: October 6, 2018; Published: November 5, 2018

\begin{abstract}
The objective of the study was to investigate the impact of the protein content of pollen on the development of the honey bee (Apis mellifera L.). The protein content of the pollen influenced the development of the honey bees, and should be taken into consideration as an essential factor. The pollen collected in different periods of the year has a different protein value. The protein content in the examined samples throughout the three seasons ranged from $13.9 \%$ to $27.8 \%$, and the average value was $20.9 \%$. Pollen from plants blooming in spring had higher protein content (21.1-27.8\%) than those from summer (13.9$23.5 \%)$ and autumn (15.1-25.1\%). The great amount of pollen that honey bees collected in spring and its richness in proteins could explain the strong growth of brood and population during this period. The development of bee colonies is higher, when honey bees collect pollen with higher protein content. The higher it is, the higher development is. During the spring the pollen with protein content over $21 \%$, and especially over $27 \%$ allows the colonies to maintain a high level of development. When autumn providing pollen with high protein content, the bee colonies grow faster in the early spring of the following year as well. Considering the fact that the new beekeeping season started at the end of August and at the beginning of September of the previous year, the amount of protein in the pollen was of great importance for rearing a large amount of brood in the early spring, when the blooming of a large number of plants had not yet begun and the bees used mainly the pollen supplies from the previous year. When the protein content is going down, the development of the bee colonies is also restricted. There is a relationship between the protein content of pollen and the development of bee colonies. This study shows, that development of the bee colonies is strongly connected by protein content of pollen, and protein content of pollen is characterized by a great dynamics of pollen sources.
\end{abstract}

Keywords: Impact, Protein Content, Pollen, Apis mellifera, Development

\section{Introduction}

Pollen provides lipids, carbohydrates, vitamins, and minerals to the bee colonies and it serves as the honey bees only protein source [1]. The development of the bee colonies has a direct relationship with the contribution and consumption of pollen [2]. The colonies terminate the rearing of brood in the absence of flowering pollen-giving plants in the nature and of protein reserves inside the hive [3]. The shortage of pollen can have significant effects, both on the strength and resilience of the colony and on honey production $[4,5]$. It is established that a lack of pollen or a lowering of its nutritional value over long-term feeding negatively affects the physiological development of bees [6]. If pollen is absent, or is kept for a long period at $18-26^{\circ} \mathrm{C}$, the amount of brood reared in colonies will be reduced [7]. In order for a bee colony to undertake its vital processes, it must be sufficiently supplied with quality protein food. Pollen containing less than $20 \%$ crude protein cannot satisfy the colony requirements for its development and optimum honey production [8].

The nutritional value of pollen varies between different plant species, and may differ significantly in amino acid composition and/or concentration, and this affects the growth of a bee colony $[9,10]$. There is a relationship between the nutritional value of pollen and the development, reproduction and productivity of bee colonies [11]. Honey bee longevity, brood rearing and honey production are all reduced when protein availability is insufficient $[12,13]$. The level of protein in bees' food significantly affects the amount of brood reared, the protein content of bee hemolymph, the metabolism, and the quality of food for the larvae [14]. Low protein content in pollen also reduces the resistance of honey 
bees to diseases [15]. Deficiency of protein in the diet of the colony can be one of the reasons for the emergence of invasion and infectious diseases [16].

The aim of this study is to identify the impact of different protein content of pollen on honey bee (Apis mellifera L.) development.

\section{Materials and Methods}

\subsection{Bee Colonies}

The study was carried out using 5 bee colonies during 2012-2014, housed in 10-frame Langstroth-Ruth hives. At the end of each month the colonies were inspected, with the following taken into account: The number of frames covered by bees- there are $1580 \pm 100$ bees on a frame, we multiply by 1580 [17]. Quantity workers brood- using measuring frame with squares of size $5 \times 5 \mathrm{~cm}\left(25 \mathrm{~cm}^{2}\right.$ area $)$. Taking into account that in $1 \mathrm{~cm}^{2}$ of comb there are 4 worker cells, then in each of the squares there are 100 worker cells, then multiply the number of squares by 100 [5].

\subsection{Pollen Collecting and Sampling}

Pollen traps were placed into the hives and the pollen pellets were harvested every 2 days from an apiary located in Belozem $42.2^{\circ}, 25.033333^{\circ}$ (Bulgaria). The collection of pollen started in April and continued until September. Each sample collected was marked with a predetermined color for each hive and date. Every single month was with two reporting periods (except April 2012- only one): I period from $1^{\text {st }}$ to $15^{\text {th }}$ day of the month and II period from $16^{\text {th }}$ to $30 / 31^{\text {st }}$ day of the month. The collected pollen from the bee colonies was mixed according to the accurate period. The random sample using for analysis for each period was taken using the quarter method of sampling. In this method the pollen was spread some on paper and divided it into four equal quarters, then removed two diagonally opposite quarters. The remaining material was mixed and quartered until the sample was reduced to the desired size.

\subsection{Protein Content Analysis}

Thirty-five vials with mixed pollen collected from all the colonies were analysed. For nitrogen content determination, the pollen was analysed using the Kjeldahl method, which is separated into three steps. During the first step, digestion, a quantity of $1 \mathrm{~g}$ of pollen was placed into the tubes of a digestion unit with $20 \mathrm{ml}$ of strong sulphuric acid $\left(\mathrm{H}_{2} \mathrm{SO}_{4}, 95-\right.$ 98\%) and heated for three and half hours in the presence of a catalyst, which assists the conversion of nitrogen in proteins to ammonium ions. When the digestion was complete, the samples were removed and left to cool at room temperature. After cooling, the ammonia was distilled in the presence of $\mathrm{NaOH}$ and collected in a solution of boric acid $\left(\mathrm{H}_{3} \mathrm{BO}_{3}, 99.5-\right.$ $100.5 \%$, which was then titrated against $0.1 \mathrm{M} \mathrm{HCl}$. The crude protein content was estimated using the factor 5.60 [18], by the volume of HCL which was taken by an instrument and added to the pollen. In this case the following formula applied:

$$
\text { Protein }(\%)=0.791 * \mathrm{~V} / \mathrm{m} \text {. }
$$

Where: $\mathrm{V}=$ the volume $(\mathrm{ml})$ of $\mathrm{HCl}$ taken during the titration. $\mathrm{M}=$ the amount of pollen $(\mathrm{g})$.

\section{Results}

During 2012 (Figure 1) and 2014 (Figure 3) the development of the bee colonies was similar. In 2012 (Figure 1) data showed that the bee colonies had the largest development in June when the number of the bees was 47400 . This was due to the large amount of brood reared in April-June (Figure 1), as a result of the high protein value of the pollen during this period (Table 1). In 2014 the largest development was recorded in May (Figure 3), when the number of the bees were 42976. This was due to the large amount of brood reared in March-May (Figure 3) because of the high protein content of the pollen during this period (Table 1) and the autumn in 2013 (Table 2), and it reflected the early rapid and strong development of the bee colonies. After the rapid and strong development, when pollen with low amount of protein content was coming into the bee colony, it began to decrease the development of the bee colonies, it also started to reduce in the past two years of research 2013 (Figure 2) and 2014 (Figure 3). In contrast, in July-September 2012 (Figure 1) and 2014 (Figure 3), when the protein started to reduce (Table 1 ), the development of the bee colonies was reduced (Figure 1 and Figure 3). In September 2014, despite the fact that the protein content of the pollen was increasing, the development was reduced to 15800 (Figure 3).

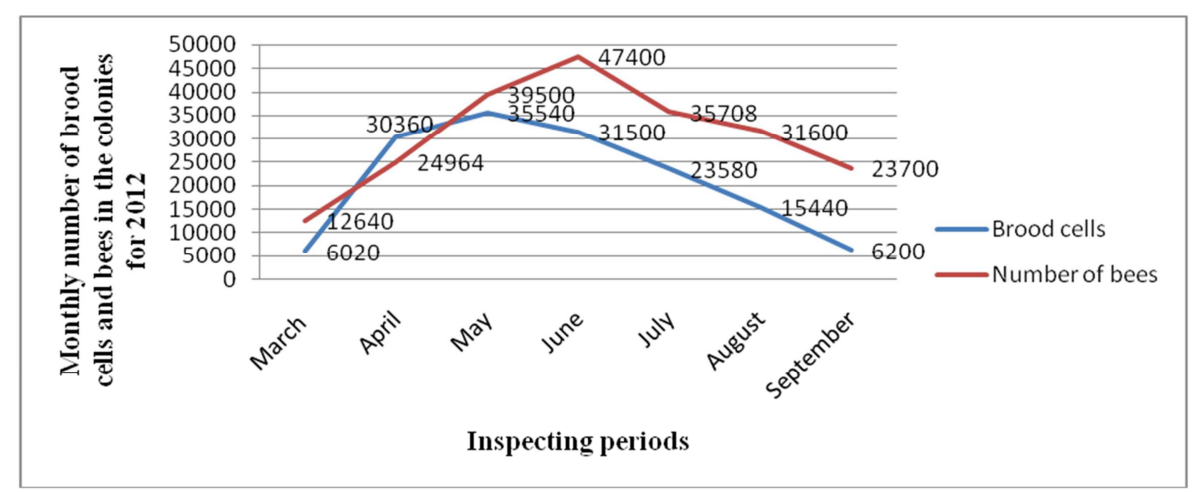

Figure 1. Dynamic of the development (population) of the bee colonies (number of bees) for 2012. 


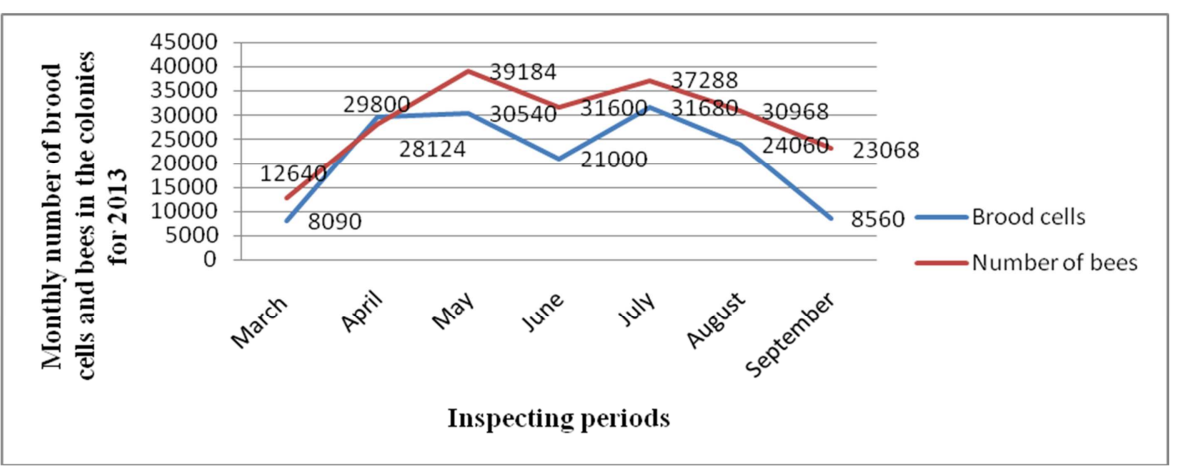

Figure 2. Dynamic of the development (population) of the bee colonies (number of bees) for 2013.

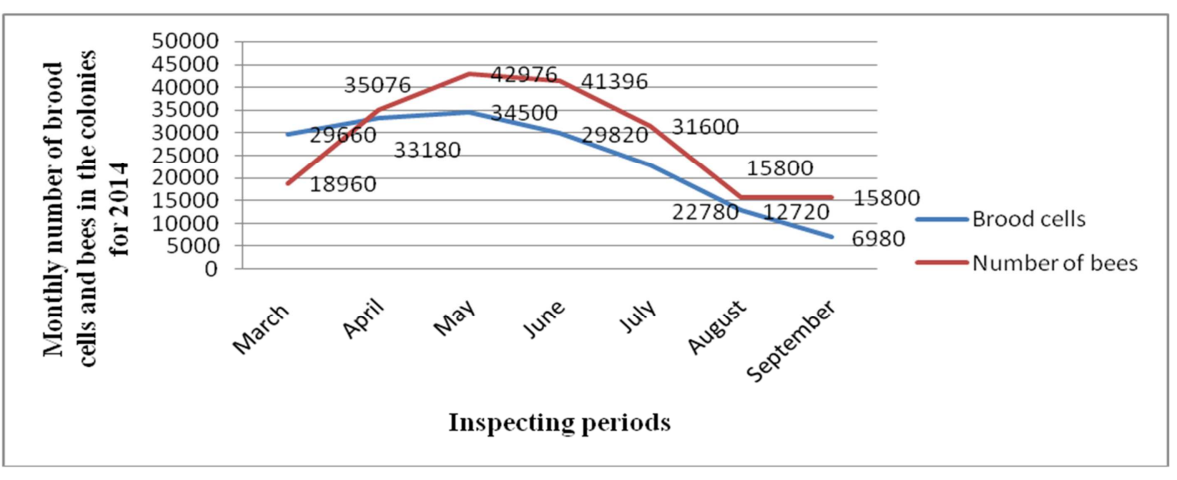

Figure 3. Dynamic of the development (population) of the bee colonies (number of bees) for 2014.

The statistical analysis (Excel) of the data during 2012 between the protein concentration of pollen (Table 1) and the development of the bee colonies (Figure 1) showed that there was a positive but no significant correlation $(\mathrm{r}=0.30, \mathrm{p} \leq$ $0.05)$. The reason for that difference was the biggest amount of brood rearing in May but it was emerged in June (Figure 1 ), and because of that the protein had low value in this period compared to April-May (Table 1). In 2014 it was found a positive high and significant correlation $(r=0.51, p \leq$ 0.05 ) between the protein concentration of the pollen (Table 1) and the development of the bee colonies (Figure 3). In 2014 (Figure 3) the correlation was more clearly expressed because of the strong early spring development of the colonies, but the lowest value was due to the fact that the protein in the autumn increased and decreased the development, which was related to the ongoing preparing of the bee colonies for wintering.

The dynamics of the protein content of the pollen in 2013 (Table 1) also influenced the development of the bee colonies but in a different way. The data provided in the Figure 2 demonstrated that the bee colonies showed the largest development in May, when the number of bees were 39184. This was due to the large amount of brood reared in April-May (Figure 2) due to the high protein content of the pollen during spring- 23.1\% (Table 2). In contrast, during June when the protein average value was $15.6 \%$ (Table 1 ), the development of the bee colonies was sharply reduced to 31600 bees. In June $2012 / 2014$ the protein content in pollen was $22.5 \% / 22.1 \%$ (Table 1) and the development of the bee colonies was 47400 and 41396 (Figure 1 and Figure 3). In the second period of July 2013 (16-31 of July) when the protein content had increased from $15.6 \%$ to $19.9 \%$ (Table 1 ), development of the bee colonies grew up again- till 37288 bees (Figure 2), which was in higher than that in July 2012 (Figure 1) and July 2014 (Figure 3). The statistical analysis during 2013 of the data between the protein concentration of the pollen (Table 1) and the development of the bee colonies (Figure 2) showed that there was a negative but no significant correlation $(\mathrm{r}=-0.21, \mathrm{p} \leq$ 0.05 ). The reason for the negative correlation is due to the fact that despite the increasing of the amount of protein in August and especially in September 2013 (Table 1), when the protein was higher even than the spring 2013 (Table 2), the bees have a biological instinct to reduce the rearing of brood and prepare for the winter period. But if looking at period May-July 2013, where we observed the essential dynamics of the crude protein content (Table 1) and the development (Figure 2) of the bee colonies the correlation was high and significant $(\mathrm{r}=0.81, \mathrm{p} \leq$ $0.05)$.

Table 1. Protein content (\%) of mixed bee collected-pollen in different harvesting periods for three years.

\begin{tabular}{llll}
\hline & $\mathbf{2 0 1 2}$ & $\mathbf{2 0 1 3}$ & $\mathbf{2 0 1 4}$ \\
\hline April 1-15 & & 21.1 & 27.8 \\
April 16-30 & 25 & 23 & 25.5 \\
April (average value) & 25 & 22 & 26.7 \\
May 1-15 & 24.6 & 23.9 & 24.8 \\
May 16-31 & 23.4 & 24.4 & 23 \\
May (average value) & 24 & 24.2 & 23.9 \\
June 1-15 & 23.5 & 15.6 & 22.5 \\
June 16-30 & 21.5 & 15.7 & 21.6 \\
June (average value) & 22.5 & 15.6 & 22.1 \\
July 1-15 & 17 & 16 & 19.2 \\
July 16-31 & 18.3 & 19.9 & 21 \\
July (average value) & 17.7 & 17.9 & 20.1 \\
\hline
\end{tabular}




\begin{tabular}{llll}
\hline & $\mathbf{2 0 1 2}$ & $\mathbf{2 0 1 3}$ & $\mathbf{2 0 1 4}$ \\
\hline August 1-15 & 17.1 & 22.8 & 20.7 \\
August 16-31 & 13.9 & 21.9 & 18.4 \\
August (average value) & 15.5 & 22.4 & 19.6 \\
September 1-15 & 15.1 & 22.6 & 19.9 \\
September 16-30 & 16 & 25.1 & 24.2 \\
September (average value) & 15.6 & 23.9 & 22 \\
\hline
\end{tabular}

Table 2. Protein content (\%) of mixed bee collected-pollen in different seasons for three years.

\begin{tabular}{llll}
\hline & $\mathbf{2 0 1 2}$ & $\mathbf{2 0 1 3}$ & $\mathbf{2 0 1 4}$ \\
\hline Sring & 24.4 & 23.1 & 25.3 \\
Summer & 18.6 & 18.6 & 20.6 \\
Autumn & 15.6 & 23.9 & 22 \\
X for year & 19.5 & 21.9 & 22.6 \\
\hline
\end{tabular}

The research during the three years showed that during the spring and early summer (April-June) the bees had an increased the amount of brood (Figure 1, Figure 2 and Figure 3 ). In 2014 the highest average protein content of the pollen$22.6 \%$ was registered compared to $2012-19.5 \%$ and $2013-$ $21.9 \%$ (Table 2), even during the summer period, the amount of protein was higher than $20 \%$ (Table 2).

\section{Discussion}

Pollen is a natural source of protein for bees, and it is necessary for honey bee development. Without the presence of flowering plants and supply of pollen in the local natural environment, bee colonies slow growing brood. The composition of pollen harvested by honey bees can vary greatly depending on the time of year, the botanical origin, and the geographic region from which the pollen is obtained [19].

Many authors have studied the impact of protein content of pollen on honey bees live. Pollen with protein content more than $20 \%$ seems to supply the needs of the nutritional requirements of the bees [8, 20-23]. It is established that in the presence of a sufficient amount of pollen containing not less than $25 \%$ protein bees can maintain a high level of vitality and productivity [24]. The study on trapped pollen from Apis mellifera colonies in the Belozem area of Bulgaria revealed in 11 mixed pollen samples that the protein content ranged from 13.88 to $25.02 \%$, and the average value was $19.45 \%$ [11]. It is found crude protein of selected pollen sources ranged from 13.9 to $25.5 \%$ [26]. Pollen from plants blooming in spring had higher protein content (20-24.7\%) than those from summer (15.1-19.9\%) and autumn (19.3$23.1 \%$ ). The great amount of pollen that honey bees collected in spring and its richness in proteins could explain the strong growth of brood and population during this period.

The determination of the protein content is fundamental in understanding pollen quality. It affect not only the development, but also and survival of the honey bee colonies. It is found in spring providing pollen with an average protein content of $24.35 \%$, colonies can maintain a high level of reproduction and development [11]. In contrast, during the autumn when the protein average is $15.57 \%$, reproduction and development of the bee colonies is reduced. Pollen collected by honey bees has a different protein value at different periods of the year.

The level of protein in the bees food significantly affects: a) the amount of brood reared, b) the protein content of bee hemolymph, c) the metabolism, and d) the quality of food for the larvae [14]. The enzyme activity at the beginning of the post-embryonic development, depends on the protein content in the diet [26]. One of the best ways to fight against dangerous diseases such as nosematosis, akarapidoza, foulbrood is by feeding the bees with pollen [5].

The results of this study showing that the impact of the protein content of the honey bee-collected pollen plays major role for honey bee development. Consequently, the local flora directly and indirectly affects the beekeeping by affecting the development of the honey bee colony.

\section{Conclusions}

The pollen collected in different periods of the year has a different protein value. The protein content in the examined pollen samples throughout the experiment ranged from $13.9 \%$ to $27.8 \%$, and the average value was $20.9 \%$. Pollen from plants blooming in spring had higher protein content than those from summer and autumn. The protein content of the mixed pollen samples is different for each year.

The development of bee colonies is higher, when honey bees collect pollen with higher protein content. The higher it is, the higher development is. During the spring the pollen with protein content over $21 \%$, and especially over $27 \%$ allows the colonies to maintain a high level of development. After rapid and strong development, when pollen with low amount of protein content was coming into the bee colony, it began to decrease the development of the bee colonies. When the protein content had increased the development of the bee colonies grew up again.

There is a relationship between the protein content of pollen and the development of bee colonies.

\section{Acknowledgements}

The author is grateful to the members of Laboratory of Apiculture-Sericulture, Department of Agriculture, Aristotle University of Thessaloniki, Greece: Andreas Thrasyvoulou, Chrysoula Tananaki, Vasilis Liolios, Dimitris Kanelis, Maria Dimou, Georios Goras, Emmanuel Karazafiris.

\section{References}

[1] Roulston, T. H. and Cane, J. H. (2000). Pollen nutritional content and digestibility for animals. Plant Systematics and Evolution, 221 (1): 187-209.

[2] Zherebkin, M. V. and Mironova, K. R. (1976). Some features in pollen collecting behavior in different species of bees. Scientific Notes Of The Institute Of Apiculture, 25: 1-63. 
[3] Avetisyan, G. A. 1983. Breeding and keeping of bees. Kolos, Moscow, 30-68.

[4] McLellan, A. R. (1974). Some effects of pollen traps on colonies of honey bees. Journal of Apicultural Research, 13 (2): 143-148.

[5] Lavrehin, F. and Pankova, S. (1983). Biology of honey bee. Kolos, Moscow, 1-301.

[6] Haydak, M. (1961). Influence of storage on the nutritive value of pollen for newly emerged honeybees. American Bee Journal, 101: 354-355.

[7] Stroykov, S. (1963). Digestibility of pollen by the bees. Beekeeping, 6: 23-25.

[8] Herbert, E. W. J. (1992). The Hive and the Honey Bee. Honey bee nutrition, In: Graham J. M. (Ed.), Dadant \& Sons. Hamilton, IL, 197-233.

[9] Day, S., Beye, R., Merce, A. and Ogde, S. (1990). The nutrient composition of honey bee-collected pollen in Otago, New Zealand. Journal of Apicultural Research, 29 (3): 138146.

[10] Roulston, T. H., Cane, J. H. and Buchmann, S. L. (2000). What governs protein content of pollen: pollinator preferences, pollen-pistil interactions or phylogeny? Ecological Monographs, 70 (4): 617-643.

[11] Radev, Zh., Liolios, V., Tananaki, C. and Thrasyvoulou, A. (2014). The Impact of the Nutritive Value of Pollen on the Development, Reproduction and Productivity of Honey Bee (Apis mellifera L.). Bulgarian Journal of Agricultural Science, 20 (3): 685-689.

[12] Crailsheim, K. (1990). The protein balance of the honey bee worker. Apidologie 21 (5): 417-429.

[13] Herbert, E. Jr. (2000). The Hive and the Honey Bee. Honey bee nutrition, In: Graham J. M. (Ed.), Dadant \& Sons. Carthage, Illinois, 197-224.

[14] Stashenko, V. (1988). Pollen harvesting by bees. Beekeeping, 9: 10-11.

[15] Matilla, H. and Otis, G. (2006). Effects of pollen availability and Nosema infection during the spring on division of labour and survival of worker honey bees (Hymenoptera: Apidae). Environmental entomology 35 (3): 708-717.
[16] Bilash, N. G. (1990). Influence the quality of pollen stocks of bees. Beekeeping 4 (4): 6-7.

[17] Argena, N. (2013). The removal of drone brood from bee colonies to control Varroa destructor investation. Master Scientific Thesis, Agriculture School, Aristotelian University Thessaloniki, 70 .

[18] Rabie, A., Wells, J. and Dent, L. 1983. The nitrogen content of pollen protein. Journal of Apicultural Research 22 (2): 119123.

[19] Linskens, H. F. and Jorde, W. (1997). Pollen as food and medicine: a review. Economic Botany, 51 (1): 78-86.

[20] Tyurner, J. V., Kleinschmidt, G. J., Kondos, A. K. and Harden J. (1972). Study of bee colonies which are involve to honey collection with two types of eucalyptus. Beekeeping Australia, $1^{\text {st }}$ Australian congress. Australia, 74-79.

[21] Shaw, D. E. (1999). Bees and fungi, with special reference to certain plants pathogens. Australian Plant Pathology, 28 (4): 269-282.

[22] Szczęsna, T. (2006). Protein content and amino acid composition of bee-collected pollen from selected botanical origins. Journal of Apicultural Science 50 (2): 81-90.

[23] Liolios, V., Tananaki, C., Dimou, M., Kanelis, D. and Thrasyvoulou, A. (2010). Protein content and sugar composition of bee-collected pollen from selected botanical origins. In: Abstracts: International Symposium on Authenticity and Quality of Bee Products and 2nd World Symposium on Honeydew Honey. Chania - Crete, 7 - 10 April 2010. Journal of ApiProduct and ApiMedical Science, 2 (3): 116

[24] Kleinschmidt, G. J., Kondos, A. K. (1977). Influence of protein contained in the food to the productivity of bee colonies. Proceeding XXVI International Congress on beekeeping. Adelaide-Australia, 356-361.

[25] Liolios, V., Tananaki, C., Dimou, M., Kanelis, D., Goras, G., Karazafiris, E. and Thrasyvoulou, A. (2016). Ranking pollen from bee plants according to their protein contribution to honey bees. Journal of Apicultural Researsh, 54 (5): 582-592.

[26] Omar, M. and Mateesku, K. (1983). Effect of food on the catalase activity during post-embryonic development of the honey bee. Proceeding XXIX International Congress on beekeeping. Budapest-Romania, 171-176. 